\title{
両側性反回神経麻痺症例の臨床的観察
}

\author{
都築 達1)・福田 宏之2) ・藤岡 正1) \\ 高山 悦代3) ・ 川井田政弘 ${ }^{4)}$
}

\section{Clinical Observations on Bilateral Recurrent Laryngeal Nerve Paralysis}

\author{
Tohru Tsuzuki and Tadashi Fujioka \\ (Dokkyo University School of Medicine Koshigaya Hospital) \\ Hiroyuki Fukuda \\ (Keio University School of Medicine) \\ Etsuyo Takayama \\ (National Defense Medical College) \\ Masahiro Kawaida \\ (Otsuka Metropolitan Hospital)
}

A clinical study was conducted on 48 patients with bilateral recurrent laryngeal nerve paralysis, 29 females and 19 males. In 38 patients (79\%), the paralysis was seen as surgical or post-operative. In a fairly large number of female patients it occurred after thyroid surgery and in males after surgery for esophageal cancer.

This paralysis was often seen in males in the 6th and 7 th decades of life, but in females seen from the 4 th to 8 th decades. Hoarseness was the most common symptom, followed by dyspnea, but dyspnea was never observed if there was more than $2 \mathrm{~mm}$ between the vocal folds. There was no significant correlation between the distance between the vocal folds and aspiration. There was also no instance of dyspnea becoming more serious, according to the answers to our questionnaire.

Key words: bilateral recurrent laryngeal nerve paralysis, clinical study, questionnaire

はじめに

喉頭は，呼吸，発声，誤嚥防止と異なった重 要な機能を行っている.したがって，声帯運動 の障害はこれらの機能に重大な影響を与える。 特に両側声帯麻痺ではこれらの機能障害が著明
となり，呼吸困難，嚥下性肺炎などの原因とな り得る. 声帯運動の制限の程度はこれらと大き く関係しているが，声帯運動が完全に麻痺して いる症例では，声門間隙の広さも関係している ものと考觉られる.
1）獨協医科大学越谷病院耳鼻咽喉科

3）防衛医科大学耳鼻咽喉科学教室
2）慶應義塾大学医学部耳鼻咽喉科学教室

4）都立大塚病院耳鼻咽喉科 
今回，我々は両側性反回神経麻痺症例につい て臨床的に検討を行い, 特に両側声帯完全麻痺 症例に括いて，声門間隙と呼吸困難，嗄声，誤 嚥，喘鳴の関係を調べた。 また，呼吸状態が長 期的にどのようになるかも調査した。

\section{対象と方法}

1977年から1984年の 8 年間に慶應義塾大学病 院耳鼻咽喉科を受診した48症例の両側性反回神 経麻痺症例についてカルテに記載された内容を もとに, 原因, 男女差, 声帯運動制限の程度, 年齢 - 性別分布, 両側声帯完全麻痺症例の症状 そついて調査した。またアンケート調査を行い， 両側声帯完全麻痺症例の現在の呼吸状態につい て追跡調査した。

\section{結果}

1 ）原因別男女別症例数

表 1 に示すように両側声帯麻痺48例中, 術後
性麻疩が38例（79\%)を占めていた．特に甲状腺 疾患術後が18例, 食道癌術後が13例であった。 非術後性は 9 例 (19\%) であるが，原因不明は 7 例であり，腫瘍疾患は乳癌の 1 例の久であった。 男女別の原因の相違についてみると，女性では 29例中16例が甲状腺術後であり, 男性でも19例 中16例が術後性であるが，食道癌術後例が多く を占めていた。

\section{2 ）年齢・性別分布}

図 1 亿年齢・性別分布を示す，男性では，50 歳代，60歳代に多くみられ，女性では，30歳代 から70歳まで広く分布していた。

3 ）麻痺の原因と麻痺の程度の関係(表 1) 両側完全麻痺は33例, 一側完全 - 一側不全麻 痺は 6 例, 両側不全麻痺は 4 例であった。非術 後性麻痺では不全麻痺が多く, 術後性麻痺では 完全麻痺が多くみられた。

表 1 両側声帯麻痺48症例の内訳

\begin{tabular}{|c|c|c|c|c|c|c|}
\hline 原 因 & 症例数 & 男 & 女 & $\begin{array}{l}\text { 両 側 } \\
\text { 完全麻櫣 } \\
\end{array}$ & $\begin{array}{l}\text { 一例不全麻㾢 } \\
\text { 一即完全麻煇 } \\
\end{array}$ & $\begin{array}{l}\text { 禹 側 } \\
\text { 不全麻梗 }\end{array}$ \\
\hline 非術後性 & 9 & 3 & 6 & 2 & 2 & 3 \\
\hline 原因不明 & 7 & 3 & 4 & 2 & 2 & 3 \\
\hline 混合麻㾝 & 1 & & 1 & & & \\
\hline 乳 癌 & 1 & & 1 & & & \\
\hline 術後性 & 38 & 16 & 22 & 30 & 4 & 1 \\
\hline 甲状腺術後 & 18 & 2 & 16 & 15 & 3 & \\
\hline 食道癌術後 & 13 & 8 & 5 & 10 & 1 & \\
\hline 心疾患術後 & 2 & 2 & & 1 & & \\
\hline 動脈癌術後 & 1 & 1 & & 1 & & \\
\hline 気管切開後 & 1 & 1 & & 1 & & \\
\hline 挿 管 性 & 1 & & 1 & & & 1 \\
\hline 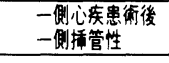 & 1 & 1 & & 1 & & \\
\hline 外傷 & 1 & 1 & & 1 & & \\
\hline 不 詳 & 1 & & 1 & 1 & & \\
\hline 計 & 48 & 19 & 29 & 33 & 6 & 4 \\
\hline
\end{tabular}


4 ）両側完全麻痺症例に括ける声門間隙と 症状の関係

両側完全麻痺33例中, カルテに症状が明記さ れている24例では, 呼吸困難を訴えている症例 は13例, 嗄声17例, 誤曣 6 例であった。 また,
声門間隙の距離と症状が記されている16例につ いて，その結果を表 2 亿示す。声門間隙の距離 は, 間接喉頭鏡下あるいは喉頭ファイバース コープ下に検者が経験的に判断した。声門間隙 が $2 \mathrm{~mm}$ 以下の症例では呼吸困難がみられ，2

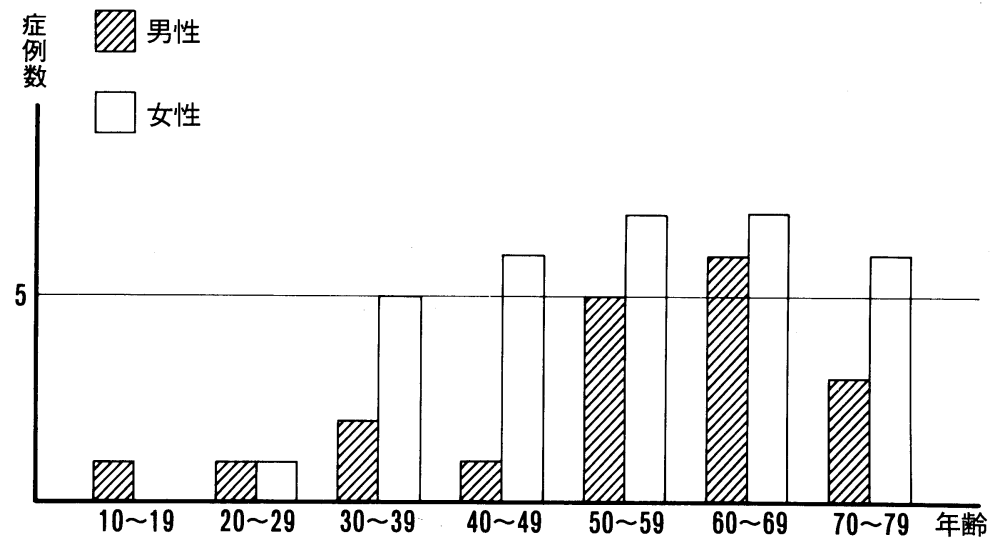

図 1 年齢・性別分布

表 2 声門間隙と症状の関係

\begin{tabular}{|c|c|c|c|c|c|}
\hline 症 例 & 声門間隙 & 呼吸困難 & 誤䓵 & 嗄声 & 喘鳴 \\
\hline 55歳 우 & 正中 & 0 & $x$ & $x$ & 0 \\
\hline 65歳 $\hat{\delta}$ & 正中 & 0 & & & 0 \\
\hline 30歳 古 & 正中近 $<$ & 0 & $x$ & & $x$ \\
\hline 74歳 ㅇ & $1 \sim 2 \mathrm{~mm}$ & 0 & & 0 & \\
\hline 48歳 ㅇ & $2 \mathrm{~mm}$ & 0 & 0 & 0 & \\
\hline 64歳 令 & 2 3mm以下 & 0 & & & 0 \\
\hline 75歳 今 & $2 \sim 3 \mathrm{~mm}$ & \begin{tabular}{|c|} 
(その後改善) \\
\end{tabular} & & & 0 \\
\hline 52歳 令 & $2 \sim 3 \mathrm{~mm}$ & $x$ & & 0 & \\
\hline 39歳 ㅇ & $2 \sim 3 \mathrm{~mm}$ & $x$ & & 0 & \\
\hline 74歳 $\hat{\delta}$ & $2 \sim 3 \mathrm{~mm}$ & $x$ & 0 & 0 & $x$ \\
\hline 59歳 우 & $3 \mathrm{~mm}$ & $x$ & $x$ & 0 & $x$ \\
\hline 35歳 우 & $3 \mathrm{~mm}$ & $x$ & $x$ & 0 & $x$ \\
\hline 69歳 $\hat{\delta}$ & 副正中位 & $x$ & & O & \\
\hline 34歳 우 & $3 \sim 4 \mathrm{~mm}$ & $x$ & $x$ & 0 & $x$ \\
\hline 48歳 우 & $4 \mathrm{~mm}$ & $x$ & $x$ & $x$ & $x$ \\
\hline 45歳 令 & 中間位 & $x$ & 0 & 0 & $x$ \\
\hline
\end{tabular}

$(\bigcirc$ : 有り, $\times$ : 無し) 
〜3 mm 以上では呼吸困難がみられなかった。 喘鳴も呼吸困難之同様であった。䛊嬩に関して は，声門間隙が広ければ誤嚥が生じやすいとい ら関係はみられなかった。嗄声は正中固定以外 の症例では，注とんどの症例が訴えていた。

5 ) 両側完全麻痺症例の呼吸状態の予後

両側完全麻疩24例に対し，現在呼吸状態がど のよらであるかアンケート調査を行った。回答 が得られた 7 症例を表 3 に示す。 3 例に声帯側 方固定が行われていた。他の 4 例については， 気管切開術を含め気道の確保を目的とした手術 は行われていない，受診時の診断では，声門間 隙は, $2 \mathrm{~mm} \sim 4 \mathrm{~mm}$ の範囲であり，初診から アンケート調査までの期間は 5 年から 10 年であ った．全症例で共通していることは，日常生活 に支障をきたすことはないといら点であった。 夜間あるい階段を昇る時に多少苦しくなると いら症例もみられたが，全体として，呼吸状態 は悪化せず，むしろ改善傾向がみられた。

\section{考案}

両側性声帯麻痺によって生じる症状は, 嗄声, 呼吸困難, 喘鳴, 䛊嚥と種々みられ, 片側麻痺
の症状は嗄声が中心であるのと比較するとかな り異なっている。また，麻痺の原因についても 相違がみられる。片側麻瘏に招将る非手術的原 因では，原因不明，悪性腫瘍が汪とんどを占め る。一般に特発性麻痺で両側声帯麻痺が生ずる ことは比較的稀である。また悪性腫痬で両側反 回神経麻痺が生ずるにはかなり腫瘍が進展して いる場合と考兄られる。図 2 は，甲状腺癌の症 例であるが，この症例でも両側不全麻㽻であっ た．胸部悪性腫瘍で両側麻瘴が生じている症例

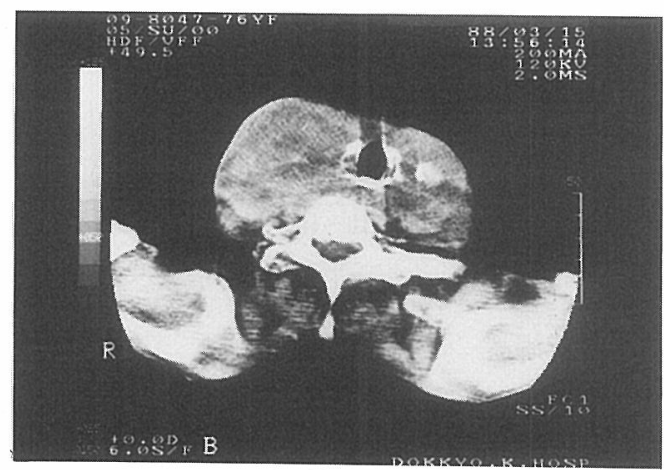

図 2 両側に巨大な甲状腺癌がみられる．

表 3 呼吸状態の予後

\begin{tabular}{|c|c|c|c|c|}
\hline 症例 & $\begin{array}{l}\text { 受診中の } \\
\text { 䠗終的な } \\
\text { 声間間隙 }\end{array}$ & 手術の有無 & 現在の呼吸状態 & 観察期間 \\
\hline 48歳 우 & $4 \mathrm{~mm}$ & 声帯側方固定術 & 夜間多少苦しくなった & 10年 \\
\hline 34歳 우 & $3 \sim 4 \mathrm{~mm}$ & 声帯側方固定術 & 階段を昇るとき苦しくなった & 10年 \\
\hline 30歳 우 & $3 \sim 4 \mathrm{~mm}$ & 声带側方固定術 & $\begin{array}{l}\text { 術後と変化なく日常生活に } \\
\text { 問題ない }\end{array}$ & 6年 \\
\hline 73歳 우 & $2 \mathrm{~mm}$ & なし & 日常生活に問題はない & 5年 \\
\hline 44歳 우 & $3 \mathrm{~mm}$ & なし & $\begin{array}{l}\text { 改㹂した } \\
\text { 階るときやや贲しい }\end{array}$ & 7 年 \\
\hline 50歳 우 & $3 \mathrm{~mm}$ & なし & 楽になった & 5年 \\
\hline 48歳 우 & $2 \sim 3 \mathrm{~mm}$ & なし & 楽になった & 9年 \\
\hline
\end{tabular}


では全身状態の覀化などで, 内科あるいは外科 で治療が行われて，耳鼻科での診察が行われず， 両側麻㽻の診断がなされていない症例も多く存 在しているものと思われる. 両側声帯麻㽻の原 因として術後性が多くみられ腫瘍性, 又は特発 性が少ないのは，これらのことも関与している ものと考光られる。

1977年から1984年に慶大耳鼻科を受診した声 帯麻痺症例は456例で, 両側声帯麻痺は48例 （10.5\%)であった。 また，他家の報告を表 4 亿 示す. 声帯麻痺症例に占める両側麻痺の比率は, 8. 3\%〜25.7\%となっているが，その原因につ いても相違がみられる. 山田ら ${ }^{1)}$, 河村ら 2) 甲状腺術後を含め手術による麻痺が少なく，そ の中で抻管性麻瘏が多いと報告している．古川 $ら^{3)}$, 長山ら ${ }^{4)}$ は手術後が多く特に甲状腺術後 が多いと報告して括り我々と似ているが，胸部 疾患術後が非常に少ない。山田らの報告では挿 管性麻痺が多くみられるがこれは統計的に有意 差はなかったと述べている．これら原因の相違 はとの施設の扔かれている状況が関与している と考觉らる。

次に症状について検討すると嗄声は最も多く みられる症状であった．これは正中位固定以外 では声門閉鎖不全が生じ，気息性嗄声となる。 また, 正中位固定でも反回神経麻痺があれば声 帯緊張が保てず，発声の効率が低下し，患者は 発声障害を訴える。いずれの場合でも嗄声とい ら訴光となり, 頻度が増加するものと考光られ
る. 誤與は, 両側完全麻痺24例中 6 例に2られ た。河村らは，片側性麻痺で副正中位固定 $28 \%$,

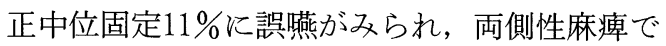
も同様の結果を示し，声門間隙が狭くても䛊嚥 が生じると述べている，我々の調査でも声門間 隙の広さと誤罣に明らかな関係はみられず，狭 い症例でも誤與がみられた。これは声門閉鎖不 全だけが誤燕の原因となっていないことを示し ている. 進ら ${ }^{5)}$ は片側反回神経麻瘏症例の原因 は声門閉鎖不全のみとは考方難く, 喉頭の知覚 脱失などが関与しているのであろうと述べてい る.

野副ら ${ }^{6)}$ は, 両側麻痺の場合呼吸困難が意外 と少ないことは興味深いことであり，この原因 は不全麻痺が多いためであると述べている。野 副らは42例中16例, 長山らは70例中22例, 河村 らは23例中 6 例が，一側あるいは両側が不全麻 痺であったと報告している．今回の調査では 10 例が不全麻痺であり, 特に非手術症例に多くみ られた。不全麻疩症例では, 呼吸困難を訴える 症例が少なくなるのは当然と思われるので, 今 回は両側完全麻痺症例の症状について調査した. 呼吸困難を訴えた症例は24例中13例で, やはり 少ないといら印象であった。すなわち呼吸困難 の頻度が少ない理由は, 不全麻痺が多いという 以外に，声帯位の関係がある。野副らは，両側 正中又は副正中位固定が42例中17例 (40.5\%)， 河村らは23例中 13 例 $(56.5 \%)$ であると報告して いる.

表 4 他家による両側反回神経麻痺症例の原因別症例数

\begin{tabular}{|c|c|c|c|c|c|c|c|c|c|c|c|}
\hline $\begin{array}{l}\text { 原因疾患 } \\
\text { 報告者 }\end{array}$ & 中枢性 & 多発慅 & 頸部 & \begin{tabular}{|l|} 
胸部 \\
疾患 \\
\end{tabular} & 特発性 & \begin{tabular}{|l|} 
甲状腺 \\
術捘 \\
\end{tabular} & 頸部 & 頸部 & \begin{tabular}{|l|l|} 
胸部 \\
述後 \\
\end{tabular} & 掩管性 & 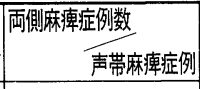 \\
\hline 山田ら" & & & 3 & 4 & 13 & 3 & & 1 & 5 & 7 & $36 / 436 \quad 8.3 \%$ \\
\hline 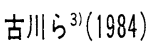 & 1 & & & & & 16 & 1 & 1 & & & $19 / 74 \quad 25.7 \%$ \\
\hline 長山ら $\left.{ }^{4}\right)(1986)$ & 3 & & 8 & 4 & 8 & 36 & 4 & 1 & 4 & 2 & $70 / 661 \quad 10.6 \%$ \\
\hline 河村 ら 2)(1987) & & 1 & 5 & 3 & 5 & 4 & 1 & & & 4 & $23 / 201 \quad 11.4 \%$ \\
\hline
\end{tabular}


両側声帯麻痺では誤與も問題であるが，やは り最も大きな問題は呼吸困難である. 気管切開 をするかどうかを客観的に決める基準はないが， 小林ら7) は, flow-volume 曲線法により，両側 声帯正中固定症例に対し声門開大術の適応基準 を示している．今回，我々は声門間隙と呼吸困 難の訴光の関係について調べた，両側完全麻痺 16例において，呼吸困難が発現するかどらかは， 声門間隙が 2 3 mm が境であり，副正中位で は呼吸困難は生じにくいとの結果となった。し たがって，声門間隙が $2 \sim 3 \mathrm{~mm}$ 以上あれば， 緊急気管切開の適応とはならないものと考兄ら れた。しかし，全身状態が悪い症例，術後の症 例，上気道感染がある症例は除外される．長期 的にみても，2 $\mathrm{mm}$ 以上声門間隙がある症例で は，呼吸は安定していた，緊急気管切開を行う かどらかを決定するためには，患者の全身状態 や精神状態，呼吸困難の訴之の程度，声帯運動 が固定するまでの期間など多くの要素を考慮し なければならず大変難しい問題である。しかし， 今後客観的に判断できる方法が確立されること が望ましい.

\section{まとめ}

1 ）1977年から1984年に慶應大学病院耳鼻咽 喉科を受診した両側反回神経麻痺48例について 臨床的に検討を行った。

2 ）男性19例，女性29例であった。

3 ) 術後性麻痺は38例であり, 甲状腺術後例 が最も多かった。

4 ）術後性麻痺では完全麻痺が，非術後性麻 痺では不全麻痺が多くみられた。

5 ) 両側完全麻痺症例飞括いて, 日常生活に
支障をきたす呼吸困難が生じないためには声門 間隙を $2 \mathrm{~mm}$ 以上必要とすることが示唆された.

6 ）誤曣と声門間陌の広さに相関はみられな かった.

7 ）追跡調查を行った結果，長期的に呼吸困 難の進行はみられず，むしろ改善傾向が得られ ると考光られた

\section{参考文献}

1）山田倫久, 佐藤意生, 平野 実, 他 : 反回神経 麻瘏の臨床統計的観察。耳喉 $53: 443 \sim 449$, 1981.

2）河村裕二，丘村 熙，湯本英二，他 : 反回神経 麻痺の臨床統計的観察. 日耳鼻 $90: 1004 \sim 1009$, 1987.

3）古川 仞, 石黒英世, 石橋陽二, 他 : 両側反回 神経麻痺の経過観察。日気食会報 $35: 1 \sim 5$, 1984.

4）長山郁生，嘉藤秀章，滝元 徹，他：過去 17 年 間にみられた反回神経麻痺の臨床統計。耳展 $29: 83 \sim 91,1986$.

5）進 武幹, 前山忠嗣, 森川郁郎, 他 : 嬿下反射 のメカニズムに関する基礎的研究. 日耳鼻 88 : 643 650, 1985.

6）野副 功, 平野 実, 進 武幹, 他 : 反回神経 麻痺の臨床統計的研究. 耳鼻 $18: 411 \sim 417$, 1972 .

7）小林武夫, 廣瀬 肇, 牛嶋達次郎, 他 : Flowvolume 曲線法に上る喉頭気管狭窄の呼吸機能 の測定. 日気食会報 $28 ： 199 \sim 204,1977$.

$\left(\begin{array}{l}\text { 原稿受付 : 平成 } 3 \text { 年 } 2 \text { 月 } 19 \text { 日 } \\ \text { 原稿採択 : 平成 } 3 \text { 年 } 3 \text { 月 } 1 \text { 日 } \\ \text { 別刷請求先 : 都築 達 } \\ \text { 干 } 350-02 \text { 埼玉県坂戸市けやき台1-1 } \\ \text { 明海大学歯学部耳鼻咽喉科学教室 }\end{array}\right)$

